\title{
$\mathrm{CSA}$ 를 사용한 플라이애시 콘크리트의 초기강도 개선을 위한 실험연구
}

\author{
박지선 ${ }^{\dagger}$ 전찬수 \\ 한국건설기술연구원
}

\section{Experiment Study on the Improvement of the Early-Age Strength of Fly Ash Concrete Using CSA}

\author{
Ji-Sun Park ${ }^{\dagger}$ and Chan-Soo Jeon \\ Department of Building Research, Korea Institute of Construction Technology, Gyeonggi-Do 411-712, Korea
}

(2013년 11월 8일 접수: 2013년 11월 14일 최종수정 : 2013년 11월 18일 채택)

\begin{abstract}
This study was performed with an aim to improve the early-age strength of concrete containing fly ash, which is known to increase the long-age strength of concrete, reduce drying shrinkage, and enhance water tightness. The composition was partially substituted with calcium sulfoaluminate (CSA), from which ettringite is actively produced, in the early stages of hydration to verify its effect on improving the early-age strength and to determine the optimal mixing ratio. For this purpose, up to $30 \%$ of the cement weight was substituted with fly ash, and the amount of CSA substitution was $8 \%$ of the fly ash weight. The mixtures were then fabricated into concrete specimens for compressive strength measurement and analysis of the correlation between the hydration products and the compressive strength.
\end{abstract}

Key words CSA, fly ash, early-age strength.

\section{1. 서 론}

\section{1 연구의 목적}

플라이애시는 콘크리트의 내구성 및 수밀성을 향상시 키고 수화열을 낮추는 데는 효과적이지만 초기활성도가 낮아 콘크리트의 초기강도(재령 3일, 7일 기준강도)가 낮 게 발현되는 사용성의 문제점이 있다. 따라서 건축 구 조물의 경우, 주로 시멘트 질량의 $10 \%$ 정도만을 대체 하여 사용하고 있으며, 댐과 같은 매스콘크리트와 콘크 리트 도로포장 공사의 경우 $30 \%$ 에서 $50 \%$ 까지 사용하 고 있다. ${ }^{1)}$

따라서 이와 같은 단점을 극복하고자 국내외에서 플라 이애시 콘크리트의 초기강도 개선을 위한 많은 연구가 진행되었다. ${ }^{2-4)}$ 주로 플라이애시의 분말도를 향상시켜 초 기 활성도를 높이거나 자극제 및 감수제를 사용하여 강 도개선을 하였다. 그러나 플라이애시의 분말도를 향상시
키거나 과도한 감수제 및 자극제의 사용은 현장 생산품 인 콘크리트의 경제성을 확보하기 어려우며, 장기 품질 의 불안정성으로 사용성에 제약이 따를 수 있다.

따라서 본 연구에서는 플라이애시 콘크리트의 경제성 확보 및 장기 강도의 안정성을 위하여 플라이애시를 시 멘트 질량의 $30 \%$ 까지 대체하고 이때 칼슘설포알루미네 이트(Calcium Sulfoaluminate 이하, CSA)를 사용하였을 경우 초기강도 개선에 관한 효과를 검증하고, 적정량의 배합비율을 제시하고자 한다.

\section{2 연구의 방법 및 범위}

플라이애시를 시멘트 질량의 $30 \%$ 까지 대체하고 초기 강도 개선을 위하여 $\mathrm{CSA}$ 를 사용한 콘크리트를 대상으 로 경화 전후의 콘크리트를 대상으로 특성실험을 수행 하였다.

굳지않은 콘크리트는 콘크리트의 공기량, 슬럼프, 응결

\footnotetext{
'Corresponding author

E-Mail : batsun@kict.re.kr (J.-S. Park, KICT)
}

(C) Materials Research Society of Korea, All rights reserved.

This is an Open-Access article distributed under the terms of the Creative Commons Attribution Non-Commercial License (http://creativecommons.org/licenses/by-nc/3.0) which permits unrestricted non-commercial use, distribution, and reproduction in any medium, provided the original work is properly cited. 
시간을 측정하여 배합비율에 따른 특성을 비교하였다. 굳 은 콘크리트는 재령 3일, 7일, 28일, 91일의 압축강도를 측정하여 강도 변화를 분석하였다. 압축강도 측정값과 공 극, 그리고 수화초기 발생하여 강도개선에 효과적으로 작 용하는 에트링가이트 발생량과의 상관성을 분석하였다.

\section{2. 실 험}

\section{1 실험변수}

콘크리트 배합 기준은 단위시멘트량 $300 \mathrm{~kg} / \mathrm{m}^{3}, 400 \mathrm{~kg} /$ $\mathrm{m}^{3}$ 을 기준으로 하였으며, 페이스트 및 모르타르와 동일 하게 플라이애시와 CSA를 혼입하였으며, 기준배합의 슬 럼프는 $150 \mathrm{~mm}$, 공기량은 $4,5 \pm 5 \%$ 로 설계하여 시험체 를 제작하였다. 잔골재, 굵은 골재, 물의 모든 배합이 동 일하다(Table 1).

\section{2 사용재료}

\subsection{1 골재}

실험에 사용한 굵은 골재는 최대치수 $25 \mathrm{~mm}$ 의 쇄석 골재로서, 표면의 미분을 세척하고 표면건조 내부포화상 태로 조정하여 사용하였다. 잔골재는 밀도가 $2.46 \mathrm{~g} / \mathrm{m}^{3}$ 인 인천산 세척해사를 사용하였다.

\subsection{2 공기연행제}

플라이애시를 사용한 콘크리트의 내구성과 품질을 향 상시키기 위하여 본 실험에서는 계면활성제를 주재료로 한 $\mathrm{AE}$ 제를 사용하였다.

\section{3 실험방법}

\subsection{1 공기량}

공기량 측정은 KS F 2421(굳지않은 콘크리트의 압력 법에 의한 공기함유량 시험방법)에 따라 워싱턴형 공기 량 측정기를 사용하여 측정하였다.

\subsection{2 슬럼프 및 플로우}

KS F 2402의 방법에 따라 슬럼프 콘(밑면내경 $200 \mathrm{~mm}$, 윗면내경 $100 \mathrm{~mm}$, 높이 $300 \mathrm{~mm}$ )에 KS F 2401(아직 굳 지않은 콘크리트의 시료채취 방법)에 따라 채취한 시료의 콘크리트 슬럼프를 측정하였으며, 모르타르의 유동성은 KS L 5111(시멘트 시험용 플로 테이블)을 사용하여 15 초간 25 회의 낙하시 흐름치를 측정하였다.

\subsection{3 응결 · 경화 특성}

플라이애시를 사용한 콘크리트의 응결·경화성능을 판 단하기 위하여 KS F 2436(관입저항침에 의한 콘크리트 응결시간 시험방법)에 의하여 콘크리트 응결·경화 실험 을 실시하였다.

\subsection{4 콘크리트 블리딩 및 소성침하}

콘크리트 비빔직후의 시간 경과에 따른 블리딩양 변화 를 관찰하기 위하여 내경 $200 \mathrm{~mm}$, 높이 $600 \mathrm{~mm}$ 의 PVC 원형통에 콘크리트 침하깊이를 지속적으로 관찰할 수 있 는 정밀도 $0.01 \mathrm{~mm}$, 측정 깊이 $50 \mathrm{~mm}$ 의 다이얼 게이지 를 부착하여 비빔 직후부터 비빔 후 20 시간까지의 침하 깊이를 측정하여 블리딩양을 계산하였다(Fig. 1).

Table 1. Concrete mix design.

\begin{tabular}{|c|c|c|c|c|c|c|c|c|c|c|}
\hline \multirow{2}{*}{$\begin{array}{c}\text { Unit } \\
\text { cement } \\
\text { amount } \\
\left(\mathrm{kg} / \mathrm{m}^{3}\right)\end{array}$} & \multirow{2}{*}{$\begin{array}{l}\text { Fly ash } \\
\text { replacement } \\
\text { ratio (\%) }\end{array}$} & \multirow{2}{*}{$\begin{array}{c}\text { CSA } \\
\text { replacement } \\
\text { ratio }(\%)\end{array}$} & \multirow{2}{*}{$\begin{array}{c}\text { Aggregate } \\
\text { content } \\
(\%)\end{array}$} & \multirow{2}{*}{$\begin{array}{c}\text { Water- } \\
\text { binder ratio } \\
(\%)\end{array}$} & \multicolumn{6}{|c|}{ Mixing ratio by weight $\left(\mathrm{kg} / \mathrm{m}^{3}\right)$} \\
\hline & & & & & Cement & Fly ash & CSA & $\begin{array}{c}\text { Fine } \\
\text { aggregate }\end{array}$ & $\begin{array}{c}\text { Coarse } \\
\text { aggregate }\end{array}$ & Water \\
\hline \multirow{7}{*}{300} & 0 & & & & 300 & 0 & & 802 & 995 & 165 \\
\hline & 10 & & & & 270 & 27 & & 800 & 990 & 165 \\
\hline & 20 & & & & 240 & 54 & & 798 & 985 & 165 \\
\hline & 30 & & 44 & 55 & 210 & 81 & & 796 & 980 & 165 \\
\hline & 10 & 0.8 & & & 270 & 25 & 2 & 800 & 990 & 165 \\
\hline & 20 & 1.6 & & & 240 & 50 & 4 & 798 & 985 & 165 \\
\hline & 30 & 2.4 & & & 210 & 75 & 6 & 796 & 980 & 165 \\
\hline \multirow{7}{*}{400} & 0 & & & & 400 & 0 & & 748 & 929 & 180 \\
\hline & 10 & & & & 360 & 40 & & 740 & 920 & 180 \\
\hline & 20 & & & & 320 & 80 & & 732 & 911 & 180 \\
\hline & 30 & & 44 & 45 & 280 & 120 & & 724 & 903 & 180 \\
\hline & 10 & 0.8 & & & 360 & 37 & 3 & 740 & 920 & 180 \\
\hline & 20 & 1.6 & & & 320 & 74 & 6 & 732 & 912 & 180 \\
\hline & 30 & 2.4 & & & 280 & 111 & 9 & 724 & 904 & 180 \\
\hline
\end{tabular}




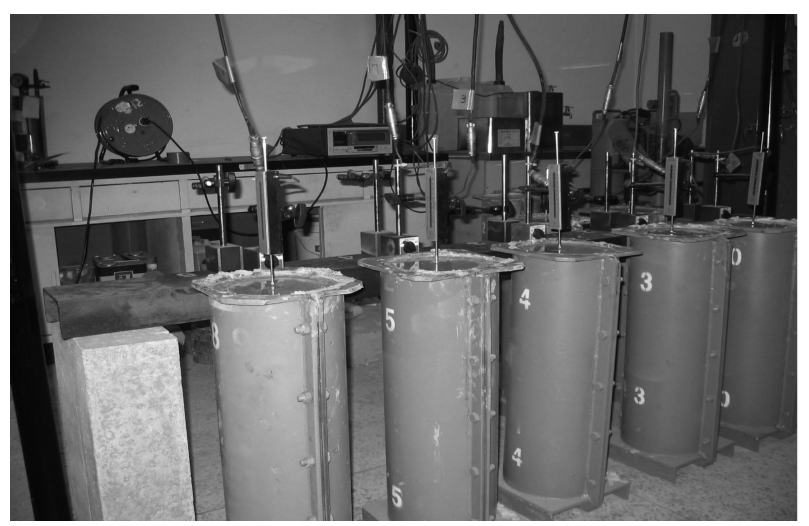

Fig. 1. Bleeding test.

\subsection{5 압축강도}

콘크리트 시험체는 $\varnothing 100 \times 200 \mathrm{~mm}$ 실험체를 제작, $23 \pm$ $1{ }^{\circ} \mathrm{C}$ 에서 수중양생한 후, 소정의 재령에서 실험을 실시 하였다. 실험체의 수는 배합요인별로 각기 5 개씩 제작하 고 평균값을 기록하였다. 압축강도 측정은 $\mathrm{KS} \mathrm{F} 2405$ (콘크리트의 압축강도 시험방법)에 따라 만능재료시험기를 사용, 매초 $0.15 \sim 0.35 \mathrm{MPa}$ 의 재하속도로 3일, 7일, 28 일, 91일 재령에서 실시하였다.

모르타르의 압축강도는 KS L 5105(수경성 시멘트 모 르타르의 압축강도 시험방법)에 따라 시험체를 제작하고 $23 \pm 1{ }^{\circ} \mathrm{C}$ 에서 수중양생한 후, 재령 3 일, 7 일, 28 일에서 압축강도 시험을 실시하였다.

\section{3. 결 과}

\section{1 공기량 측정 결과}

본 실험에서는 시멘트만을 사용한 배합의 공기량을 $4.5 \pm$ $2.0 \%$ 으로 설정하고 플라이애시 및 $\mathrm{CSA}$ 의 대체에 따른 공기량 차이를 관찰하기 위하여 동일한 양의 $\mathrm{AE}$ 제를 첨 가하고 이때의 공기량 변동을 관찰하였다.

Table 2에 나타난 바와 같이 시멘트만을 사용한 배합 의 공기량은 $4.1 \sim 4.2 \%$ 를 갖는 것으로 측정되어 공기량 범위 한계인 $4.5 \pm 0.5 \%$ 를 만족하였다.

일반적으로 콘크리트에 플라이애시를 첨가할 경우 미

Table 2. Results of measuring the air content of concrete.

\begin{tabular}{ccc}
\hline \multirow{2}{*}{ Specimen } & \multicolumn{2}{c}{ Air content (\%) } \\
& $300 \mathrm{~kg} / \mathrm{m}^{3}$ & $400 \mathrm{~kg} / \mathrm{m}^{3}$ \\
\hline FA 0 & 4.2 & 4.1 \\
FA 10 & 4.7 & 3.9 \\
FA 20 & 4.3 & 3.9 \\
FA 30 & 4.0 & 3.8 \\
FA 10 C8 & 4.6 & 3.9 \\
FA 20 C8 & 4.3 & 3.8 \\
FA 30 C8 & 4.5 & 3.7 \\
\hline
\end{tabular}

연탄소분이 공기에 흡착하여 콘크리트내의 기포를 소멸 시키는 역할을 한다. 그러나 본 실험 결과 단위시멘트 량 $300 \mathrm{~kg} / \mathrm{m}^{3}$ 의 배합에서는 플라이애시의 첨가량에 따른 공기량의 하락은 없는 것으로 나타났다.

$\mathrm{CSA}$ 를 혼합할 경우 플라이애시를 혼입하지 않은 배합 에 비하여 공기량이 높게 나타났다. 또한 단위시멘트량 $400 \mathrm{~kg} / \mathrm{m}^{3}$ 배합의 경우 공기량의 저하가 크지 않았는데 이와 같이 플라이애시 혼입에도 불구하고 공기량의 저 하가 없는 것은 사용된 플라이애시의 강열감량이 $0.3 \%$ 로서 매우 낮아 미연탄소분에 의한 공기량 저감 요소가 없기 때문인 것으로 판단된다. 즉, 일반적인 플라이애시 의 강열감량은 $4 \sim 5 \%$ 대로 미연탄소분의 함량이 높아 이 들이 기포에 흡착하여 공기량을 저하시키는 요인으로 작 용하나 본 실험에 사용된 플라이애시는 미연탄소분이 매 우 작아 이러한 공기량 감소 원인이 없기 때문으로 판 단된다. ${ }^{5}$

$\mathrm{CSA}$ 를 $8 \%$ 배합한 시험체의 경우도 공기량의 변동에 큰 영향을 미치지 않는 것으로 나타났다. $\mathrm{CSA}$ 의 강열감 량은 $0.1 \%$ 정도로서 불순물의 함유량이 매우 낮기 때문 에 공기량에 영향을 미치는 요소가 매우 적고, 결합재중 $\mathrm{CSA}$ 가 차지하는 비율이 최대 $2.4 \%$ 로 매우 적기 때문 에 플라이애시만을 사용한 배합과 큰 차이가 없는 것으 로 판단된다.

\section{2 슬럼프 및 플로우}

슬럼프 측정 결과는 Table 3 과 같다. 단위시멘트량 $300 \mathrm{~kg} / \mathrm{m}^{3}$ 에서는 플라이애시의 혼입률이 증가할수록 슬 럼프는 높아지며, CSA $8 \%$ 를 첨가할 경우 플라이애시 만을 사용한 배합보다 $10 \sim 20 \mathrm{~mm}$ 정도 더 슬럼프가 개 선되는 것으로 나타났다. 그러나 단위시멘트량 $400 \mathrm{~kg} / \mathrm{m}^{3}$ 에서는 플라이애시 증가량에 따른 슬럼프 개선 효과는 있 으나 CSA의 첨가량에 따른 슬럼프의 변동은 크지 않은 것으로 나타났다. 단위시멘트량 $400 \mathrm{~kg} / \mathrm{m}^{3}$ 은 기준배합의 슬 럼프가 $160 \mathrm{~mm}$ 로 높게 나타나 플라이애시 및 $\mathrm{CSA}$ 첨 가량에 따른 영향이 크게 작용하지 않은 것으로 판단된다.

Table 3. Slump and flow of concrete.

\begin{tabular}{ccccc}
\hline & \multicolumn{2}{c}{$300 \mathrm{~kg} / \mathrm{m}^{3}$} & \multicolumn{2}{c}{$400 \mathrm{~kg} / \mathrm{m}^{3}$} \\
Specimen & $\begin{array}{c}\text { Slump } \\
(\mathrm{mm})\end{array}$ & $\begin{array}{c}\text { Flow } \\
(\mathrm{mm})\end{array}$ & $\begin{array}{c}\text { Slump } \\
(\mathrm{mm})\end{array}$ & $\begin{array}{c}\text { Flow } \\
(\mathrm{mm})\end{array}$ \\
\hline FA 0 & 130 & 230 & 160 & 270 \\
FA 10 & 145 & 260 & 175 & 280 \\
FA 20 & 160 & 280 & 190 & 300 \\
FA 30 & 170 & 295 & 195 & 325 \\
FA 10 C8 & 160 & 275 & 170 & 280 \\
FA 20 C8 & 180 & 310 & 185 & 305 \\
FA 30 C8 & 175 & 245 & 190 & 295 \\
\hline
\end{tabular}


슬럼프 플로우를 측정한 결과, 단위시멘트량에 관계없 이 플라이애시의 대체량이 증가할수록 플로우값은 증가 하였으며, $\mathrm{CSA}$ 를 대체할 경우에는 상대적으로 증가폭은 낮게 나타났다. 특히 플라이애시를 $30 \%$ 대체하고 CSA 를 $8 \%$ 첨가하였을 경우 단위시멘트량 $300 \mathrm{~kg} / \mathrm{m}^{3}$ 에서는 $245 \mathrm{~mm}$, 단위시멘트량 $400 \mathrm{~kg} / \mathrm{m}^{3}$ 에서는 $290 \mathrm{~mm}$ 로 시멘 트만을 사용한 배합과 거의 유사하게 나타났다. 이와 같 이 CSA를 사용할 경우 플라이애시 배합보다 플로우가 낮은 것은 $\mathrm{CSA}$ 에 포함되어 있는 석고의 점참력에 의하 여 입자간 결합력이 다소 강하기 때문인 것으로 판단된다.

\section{3 응결시간}

플록터 관입시험은 굳지않은 모르타르를 용기에 담아 일정시간이 경과할 때마다 관입침을 $50 \mathrm{~mm}$ 깊이까지 밀 어 넣었을 때 관입저항값이 $3.5 \mathrm{MPa}$ 일 때 초결로 하고 $28 \mathrm{MPa}$ 일 때를 종결로 하였다.

실험결과, Table 4 와 같이 플라이애시의 함유량이 증 가할수록 응결시간은 길어지고 초결과 종결 시간의 차 도 길어진다. $\mathrm{CSA}$ 를 첨가할 경우 응결시간은 플라이애 시만을 사용할 때보다 단축되는 것으로 나타났다.

초결 후 종결까지의 시간차를 비교한 결과 시멘트를 사 용한 배합이 약 2.3 시간이 소요되었으며, 플라이애시를 $30 \%$ 대체할 경우 3 시간이 소요되나, $\mathrm{CSA}$ 의 배합은 2.7 시간으로 응결이 빠르게 진행되었다.

\section{4 콘크리트 블리딩 소성침하}

Fig. 2는 단위시멘트량 $300 \mathrm{~kg} / \mathrm{m}^{3}$ 의 소성침하 깊이를 나 타낸 것이다. 시멘트를 사용한 배합의 20 시간 후 소성침 하 깊이는 $2.91 \mathrm{~mm}$ 로 나타났으며, 플라이애시를 $30 \%$ 대 체한 FA 30 배합의 소성 침하 깊이가 $4.50 \mathrm{~mm}$ 로 가장 높은 침하를 보였다. 플라이애시 대체량이 증가할수록 소 성 침하량은 증가하는 것으로 나타났다. 즉, 플라이애시 의 양이 증가할수록 시멘트 배합에 비하여 $18 \sim 54 \%$ 의 침하량이 증가한 것으로 나타났다.

Fig. 3 은 단위시멘트량 $400 \mathrm{~kg} / \mathrm{m}^{3}$ 의 소성 침하 깊이를

Table 4. Results of measuring the setting time affected by the penetration resistance (Unit cement amount: $300 \mathrm{~kg} / \mathrm{m}^{3}$ ).

\begin{tabular}{cccc}
\hline Specimen & \multicolumn{2}{c}{ Setting time (hour) } & $\begin{array}{c}\text { Difference } \\
\text { (hour) }\end{array}$ \\
\hline FA 0 & 5.4 & 7.7 & 2.3 \\
FA 10 & 6.0 & 8.3 & 2.3 \\
FA 20 & 6.2 & 9.0 & 2.8 \\
FA 30 & 7.7 & 10.7 & 3.0 \\
FA 10 C8 & 5.6 & 7.9 & 2.3 \\
FA 20 C8 & 5.9 & 8.2 & 2.3 \\
FA 30 C8 & 7.0 & 9.7 & 2.7 \\
\hline
\end{tabular}

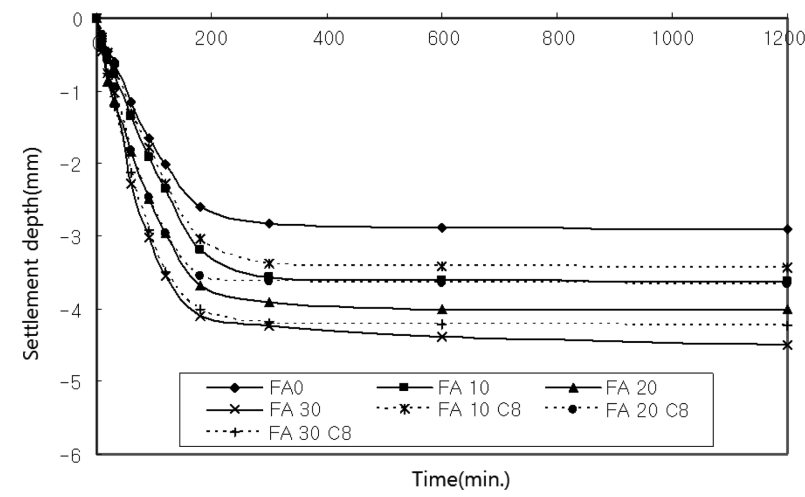

Fig. 2. Results of measuring concrete bleeding (unit cement amount: $300 \mathrm{~kg} / \mathrm{m}^{3}$ ).

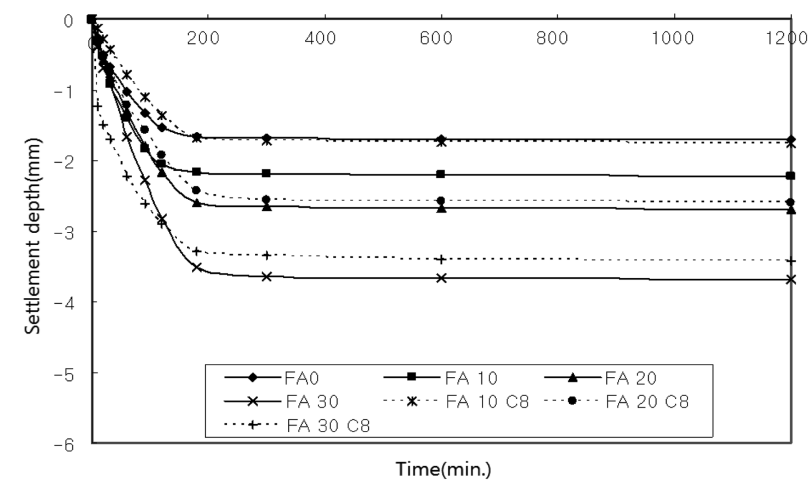

Fig. 3. Results of measuring concrete bleeding (unit cement amount: $400 \mathrm{~kg} / \mathrm{m}^{3}$ ).

나타낸 것으로 타설후 60 분에서 시멘트 배합의 침하깊 이는 $1.03 \mathrm{~mm}$ 를 보였으며, 플라이애시 대체량이 증가할 수록 침하깊이는 깊어진다. 그러나 플라이애시 치환량 $10 \%$ 에 CSA를 혼합할 경우 $0.79 \mathrm{~mm}$ 로 오히려 시멘트 배합에 바하여 낮은 침하량을 보였으며 120 분까지 계속 적인 유지를 하다가 이후에 시멘트 배합에 비하여 침하 량이 깊어지는 것을 알 수 있다.

이상과 같이 플라이애시 치환량이 증가할수록 블링딩 량이 증가하는 것은 동일한 물결합재비를 유지할 경우 입자의 형상이 구형을 형태를 가진 플라이애시가 볼-베 어링 효과에 콘크리트내에서 유동성이 증가하였기 때문 인 것으로판단한다. 또한 $\mathrm{CSA}$ 를 첨가할 경우 미세한 블 리딩 감소 효과가 있는 것은 수화특성에서 분석한 바와 같이 에트링가이트 생성에 따른 초기경화가 다소 빠르 게 진행되었기 때문으로 판단된다. Table 5 는 응결시간 측정결과를 정리한 것이다.

\section{4. 압축강도와 수화특성과의 상관성 분석}

\section{1 콘크리트의 압축강도와 배합비}

플라이애시 및 $\mathrm{CSA}$ 를 혼입한 콘크리트의 압축강도 실 
Table 5. Results of measuring concrete bleeding (plastic settlement).

\begin{tabular}{|c|c|c|c|c|c|c|c|c|c|c|c|c|}
\hline \multicolumn{2}{|c|}{ 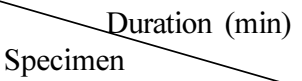 } & 0 & 10 & 20 & 30 & 60 & 90 & 120 & 180 & 300 & 600 & 1200 \\
\hline \multirow{7}{*}{300} & FA 0 & 0 & -0.25 & -0.46 & -0.62 & -1.16 & -1.65 & -2.18 & -2.75 & -2.84 & -2.89 & -2.91 \\
\hline & FA10 & 0 & -0.34 & -0.55 & -0.77 & -1.35 & -1.91 & -2.36 & -3.20 & -3.57 & -3.62 & -3.62 \\
\hline & FA20 & 0 & -0.41 & -0.87 & -1.13 & -1.85 & -2.49 & -2.97 & -3.68 & -3.92 & -4.01 & -4.01 \\
\hline & FA30 & 0 & -0.46 & -0.76 & -1.02 & -2.28 & -3.01 & -3.55 & -4.10 & -4.23 & -4.39 & -4.50 \\
\hline & FA10 C8 & 0 & -0.27 & -0.48 & -0.70 & -1.31 & -1.79 & -2.28 & -3.04 & -3.39 & -3.43 & -3.44 \\
\hline & FA20 C8 & 0 & -0.22 & -0.58 & -0.96 & -1.82 & -2.47 & -2.97 & -3.56 & -3.63 & -3.64 & -3.66 \\
\hline & FA30 C8 & 0 & -0.29 & -0.76 & -1.22 & -2.13 & -2.93 & -3.50 & -4.01 & -4.20 & -4.22 & -4.23 \\
\hline \multirow{7}{*}{400} & FA 0 & 0 & -0.27 & -0.50 & -0.67 & -1.03 & -1.33 & -1.54 & -1.66 & -1.68 & -1.70 & -1.70 \\
\hline & FA10 & 0 & -0.31 & -0.52 & -0.91 & -1.40 & -1.84 & -2.05 & -2.16 & -2.18 & -2.21 & -2.22 \\
\hline & FA20 & 0 & -0.29 & -0.58 & -0.83 & -1.31 & -1.79 & -2.17 & -2.60 & -2.65 & -2.68 & -2.70 \\
\hline & FA30 & 0 & -0.40 & -0.70 & -0.87 & -1.66 & -2.29 & -2.82 & -3.51 & -3.64 & -3.67 & -3.68 \\
\hline & FA10 C8 & 0 & -0.14 & -0.27 & -0.43 & -0.79 & -1.10 & -1.36 & -1.68 & -1.73 & -1.75 & -1.76 \\
\hline & FA20 C8 & 0 & -0.32 & -0.53 & -0.76 & -1.21 & -1.57 & -1.92 & -2.43 & -2.56 & -2.59 & -2.61 \\
\hline & FA30 C8 & 0 & -1.23 & -1.50 & -1.71 & -2.22 & -2.61 & -2.90 & -3.29 & -3.35 & -3.40 & -3.42 \\
\hline
\end{tabular}

Table 6. Results of compressive strength.

\begin{tabular}{|c|c|c|c|c|c|c|c|}
\hline \multirow{2}{*}{ Specimen } & \multirow{2}{*}{$\begin{array}{l}\text { Unit cement amount } \\
\qquad\left(\mathrm{kg} / \mathrm{m}^{3}\right)\end{array}$} & \multirow{2}{*}{$\begin{array}{l}\text { Fly ash mixing } \\
\text { ratio }(\%)\end{array}$} & \multirow{2}{*}{$\begin{array}{l}\text { CSA mixing } \\
\text { ratio }(\%)\end{array}$} & \multicolumn{4}{|c|}{ Compressive strength $(\mathrm{MPa})$} \\
\hline & & & & 3 days & 7 days & 28 days & 91 days \\
\hline FA0 & & 0 & - & 14.2 & 19.5 & 21.9 & 26.5 \\
\hline FA10 & & 10 & - & 12.4 & 16.3 & 19.6 & 25.7 \\
\hline FA20 & & 20 & - & 10.9 & 13.9 & 18.3 & 27.1 \\
\hline FA30 & 300 & 30 & - & 7.7 & 11.6 & 17.9 & 23.2 \\
\hline FA10 C8 & & 10 & 0.7 & 14.4 & 18.3 & 23.9 & 29.4 \\
\hline FA20 C8 & & 20 & 1.4 & 13.7 & 18.3 & 23.7 & 30.9 \\
\hline FA30 C8 & & 30 & 2.2 & 12.1 & 17.2 & 23.3 & 32.7 \\
\hline FA0 & & 0 & - & 19.5 & 23.1 & 30.0 & 37.3 \\
\hline FA10 & & 10 & - & 17.3 & 22.6 & 27.9 & 29.5 \\
\hline FA20 & & 20 & - & 15.4 & 19.0 & 26.9 & 32.0 \\
\hline FA30 & 400 & 30 & - & 14.2 & 18.3 & 25.3 & 35.7 \\
\hline FA10 C8 & & 10 & 0.8 & 20.1 & 25.4 & 31.5 & 40.1 \\
\hline FA20 C8 & & 20 & 1.6 & 18.9 & 25.2 & 32.2 & 42.5 \\
\hline FA30 C8 & & 30 & 2.4 & 18.4 & 23.3 & 30.3 & 45.7 \\
\hline
\end{tabular}

험결과는 Table 6과 같다. 표에서와 같이 플라이애시만 을 사용할 경우 압축강도는 28 일까지 모든 배합이 기준 배합에 비하여 낮게 나타났으며, 재령 91일에서는 플라 이애시 대체율 $20 \%$ 까지 시멘트 배합보다 높은 강도를 발현하였다.

\subsection{1 플라이애시만을 사용한 실험체}

Fig. 4에서와 같이 단위시멘트량 $300 \mathrm{~kg} / \mathrm{m}^{3}$ 배합의 3 일 강도는 플라이애시 대체율 $10 \%, 20 \%, 30 \%$ 일 때 시멘트 배합에 비하여 각각 $87 \%, 76 \%, 54 \%$ 의 강도 를 발현하였으며, 재령 7 일에서는 $84 \%, 71 \%, 59 \%$ 로 오히려 재령 3 일보다 강도발현율이 낮은 경향으로 나타 났다. 재령 28 일에서는 $89 \%, 84 \%, 82 \%$ 로 재령 3 일,
7일에 비하여 플라이애시 첨가량이 증가할수록 강도발현 이 증가한 것으로 나타났다. 플라이애시 대체율이 $10 \%$ 이상일 경우 3 일, 7 일 강도 하락률이 높아 구조안정성 및 콘크리트 품질에 좋지 않은 영향을 미칠 수 있을 것 으로 판단된다.

단위시멘트량에 따른 강도변화를 비교한 결과 단위시 멘트량 $400 \mathrm{~kg} / \mathrm{m}^{3}$ 배합은 $300 \mathrm{~kg} / \mathrm{m}^{3}$ 배합에 비하여 플 라이애시 첨가에 따른 강도 증진 효과가 높은 것으로 나 타났다.

Fig. 5에서 나타낸 바와 같이 단위시멘트량 $400 \mathrm{~kg} / \mathrm{m}^{3}$ 배합의 재령 3 일 강도의 경우, 플라이애시 대체량이 10 , $20,30 \%$ 일 때 $89 \%, 79 \%, 73 \%$ 로 대체량 $10 \%$ 에서 는 큰 차이점이 없으나 $20,30 \%$ 로 증가할수록 강도의 하 


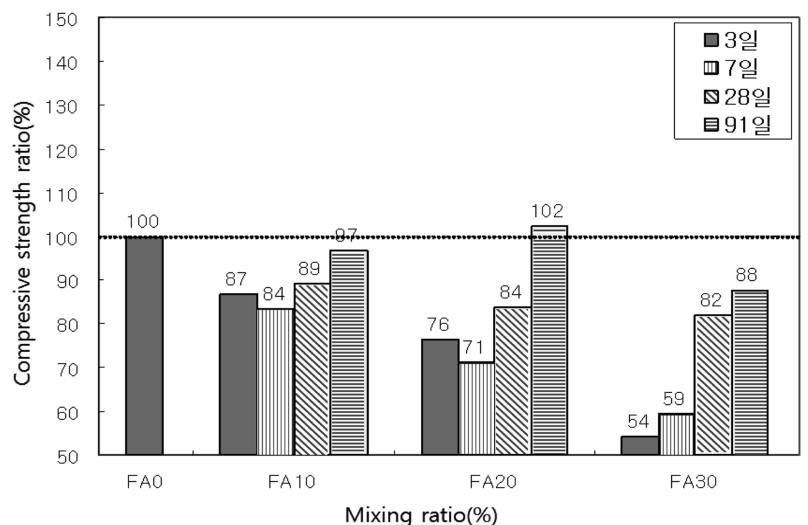

Fig. 4. Compressive strength ratio of cement mixes (Unit cement weight: $300 \mathrm{~kg} / \mathrm{m}^{3}$ ).

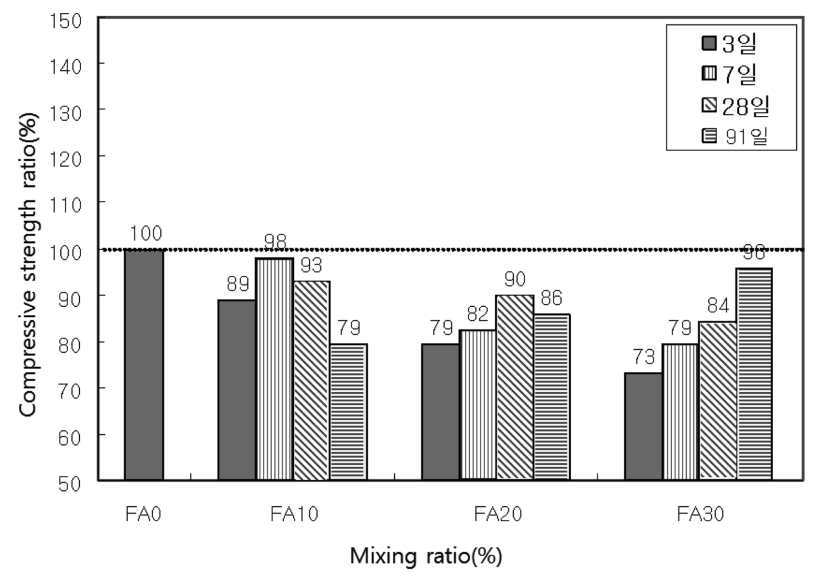

Fig. 5. Compressive strength ratio of cement mixes (Unit cement weight: $400 \mathrm{~kg} / \mathrm{m}^{3}$ ).

락이 큰 것으로 나타났다. 재령 7일의 경우는 차이가 더 욱 커져, $10 \%$ 배합할 경우 단위시멘트량 $400 \mathrm{~kg} / \mathrm{m}^{3}$ 에서 는 시멘트 배합과 동일한 강도를 나타내고, 플라이애시 대체률 $20 \%, 30 \%$ 에서도 압축강도비가 $80 \%$ 이상을 가 지고 있어 단위시멘트량 $300 \mathrm{~kg} / \mathrm{m}^{3}$ 에 비하여 $20 \%$ 이상 압축강도비가 상승된다.

이상과 같이 시멘트 혼화재료로써 플라이애시만을 사용 할 경우 초기강도 하락 등의 원인으로 인하여 $10 \%$ 이 상을 사용하기에는 어려울 것으로 판단된다. 특히 단위시 멘트량이 낮은 배합일수록 플라이애시 첨가에 따른 강도 하락률이 큰 것으로 나타나 배합설계시 이를 유념하여야 할 것으로 판단된다. 또한 플라이애시 사용량이 $10 \%$ 정 도일지라 하더라도 시멘트만을 사용한 배합에 비하여 3 일, 7일 강도하락 비율이 상대적으로 높게 나타났다.

\subsubsection{CSA를 사용한 실험체}

단위시멘트량 $300 \mathrm{~kg} / \mathrm{m}^{3}$ 배합에서는 Fig. 6 에서 나타 낸 바와 같이 $\mathrm{CSA}$ 를 플라이애시 사용량의 $8 \%$ 혼합한

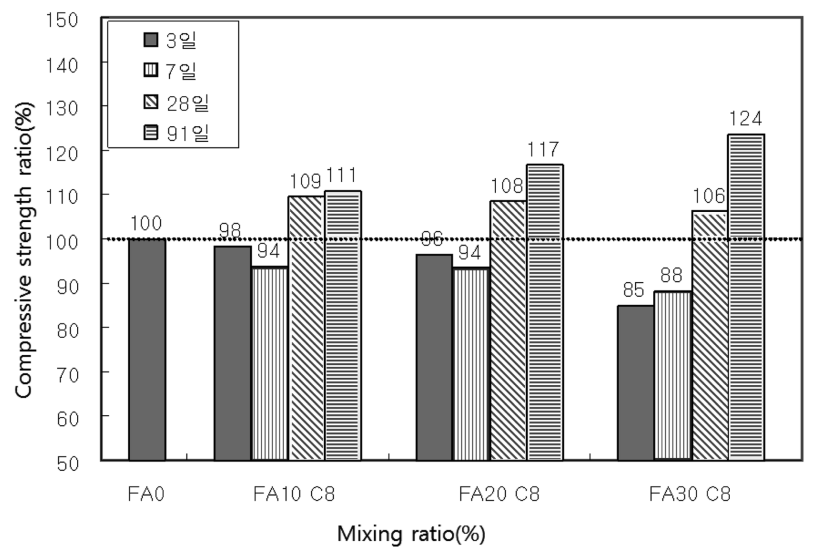

Fig. 6. Compressive strength ratio of cement mixes (Unit cement weight: $300 \mathrm{~kg} / \mathrm{m}^{3}$ ).

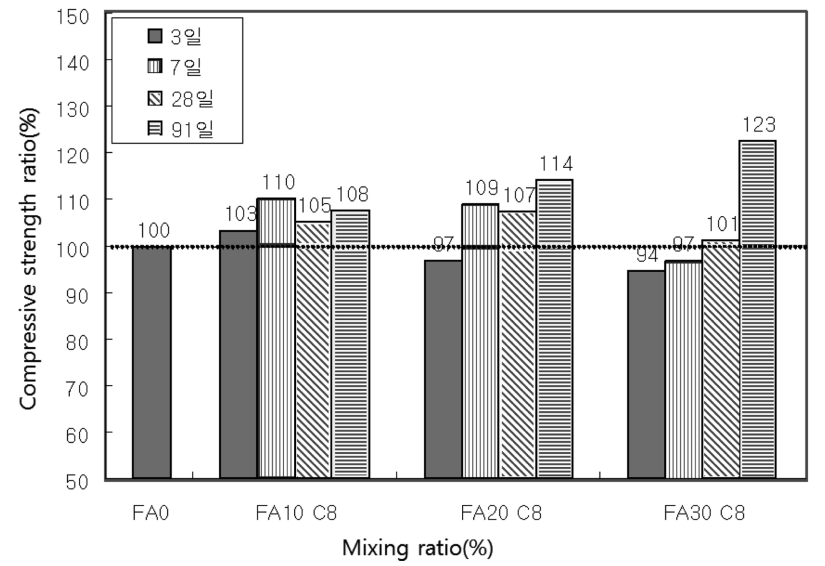

Fig. 7. Compressive strength ratio of cement mixes (Unit cement weight: $400 \mathrm{~kg} / \mathrm{m}^{3}$ ).

경우, 재령 3 일에서는 $94 \%, 78 \%, 71 \%$ 의 압축강도비 를 나타내었으며, 재령 7 일에서는 $86 \%, 74 \%, 65 \%$ 의 강도비를 나타내었다. 이와 같이 재령 3일이 재령 7일 보다 압축강도비가 높게 나오는 것은 일반 시멘트만을 사용한 배합의 초기강도 증진율이 더욱 크기 때문인 것 으로 판단된다. 재령 28 일에서는 $98 \%, 86 \%, 84 \%$ 의 강도비를 나타내어 7일 이후 압축강도의 증진이 빠르게 나타난 것을 알 수 있다. 재령 91일에서는 시멘트만을 사용한 배합과 동일한 강도를 발현하는 것으로 나타났 다. 플라이애시만을 사용한 배합과 비교하였을 경우 재 령 3 일에서는 압축강도 증진율이 7 17\% 이상 증가한 것으로 나타났으며, 특히 플라이애시의 사용량이 많은 $30 \%$ 배합에서 $17 \%$ 의 강도 증진율이 있는 것으로 나 타나 CSA 첨가에 따른 강도 개선 효과가 있는 것으로 나타났다.

단위시멘트량 $400 \mathrm{~kg} / \mathrm{m}^{3}$ 배합은 Fig. 7에서 나타낸 바 와 같이 플라이애시 대체율이 $10 \%, 20 \%, 30 \%$ 일 때 재령 3 일의 압축강도비가 $93 \%, 86 \%, 78 \%$ 로 단위시멘 
트량 $300 \mathrm{~kg} / \mathrm{m}^{3}$ 에 비하여 높은 강도 증진 효과가 있었 으며, 특히 재령 7 일의 경우 플라이애시 사용량 $10 \%$ 배 합은 시멘트만을 사용한 배합과 유사한 $101 \%$ 의 압축강 도비를 가지는 것으로 나타났다. 전반적으로 단위시멘트 량이 증가할수록 CSA 및 플라이애시 함유량에 따른 압 축강도 증진 효과가 큰 것으로 나타났으며, $\mathrm{CSA}$ 를 첨 가할 경우 플라이애시를 사용한 배합보다 $4 \sim 5 \%$ 의 강 도 증진 효과를 발휘하였다.

이상과 같이 $\mathrm{CSA}$ 를 $8 \%$ 첨가할 경우 플라이애시만을 대체한 배합에 비하여 재령 3 일까지의 강도가 증진되는 것은 초기 에트링가이트 생성량이 플라이애시만을 사용 한 배합보다 활발하여 초기에 강도 저하의 주요 원인으 로 작용하는 모세관 공극의 감소와, 에트링가이트 섬유 상이 강도보강에 효과적으로 작용하였기 때문으로 판단 한다.

\section{2 공극과 압축강도}

본 실험에서는 경화체의 공극 특성을 분석함에 있어 골 재에 의한 계면의 크랙이나 공극의 분포 때문에 발생할 수 있는 측정의 불균일을 최소화하기 위하여 분체에 의 한 시료를 제작하였고 동일배합의 모르타르 및 콘크리트 공시체와 강도를 비교하였다.

Fig. 8과 9는 시멘트 경화체에 생성된 유효공극량을 측 정한 것으로서 콘크리트 강도에 영향을 미칠 수 있는 $3 \mathrm{~nm} 30 \mu \mathrm{m}$ 범위의 공극량과 동일 배합의 압축강도와의 상관성을 분석한 것이다.

Fig. 8의 공극량과 압축강도를 비교한 그래프를 보면, 단위시멘트량 $300 \mathrm{~kg} / \mathrm{m}^{3}$ 의 경우 공극량이 $0.2 \sim 0.4 \mathrm{~mL} / \mathrm{g}$ 의 범위에 분포하고 있을 때 9 $13 \mathrm{MPa}$ 범위의 압축강 도를 나타내고 있으며, 공극이 증가할수록 압축강도는 정 비례로 낮아지는 경향으로 나타났다. 단위시멘트량 400 $\mathrm{kg} / \mathrm{m}^{3}$ 배합은 $300 \mathrm{~kg} / \mathrm{m}^{3}$ 배합보다 상관성은 낮지만 유 효공극량인 $0.2 \sim 0.4 \mathrm{~mL} / \mathrm{g}$ 의 범위에 일정한 경향으로 $14 \sim 19$

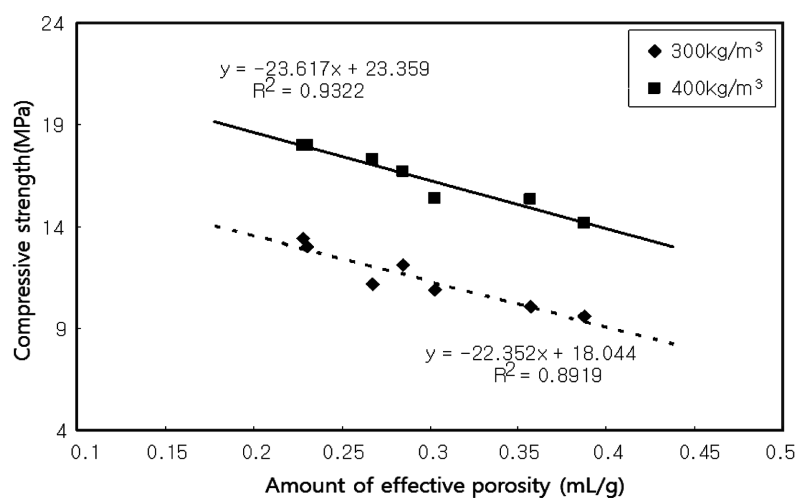

Fig. 8. Correlation between the compressive strength and effective porosity of concrete specimens.
$\mathrm{MPa}$ 의 압축강도를 발현하여 공극량이 증가할수록 강도 는 하락하는 경향을 보인다. 이와 같은 압축강도에 영 향을 주는 유효공극량의 증가는 반대로 강도의 저하를 초래할 수 있는 요인으로 작용하는 것으로 판단되며, $\mathrm{CSA}$ 대체로 인한 수화생성물의 촉진작용으로 공극을 감 소하여 강도 개선을 할 수 있을 것으로 판단된다.

Fig. 9는 공극률과 압축강도와의 상관성을 나타낸 것 으로 유효공극량과 마찬가지로 공극의 비율이 증가할수 록 콘크리트 및 모르타르의 압축강도는 낮아지는 경향 으로 나타났다.

이와 같이 공극의 대소에 따른 압축강도의 차이는 공 극 내에 존재하는 모세관공극 등은 역학적으로 매우 취 약한 성질을 가지고 있기 때문이다. 즉, 콘크리트 경화 체에 압축력이 가해질 경우 상대적으로 취약한 공극과 골재와 경계면의 크랙 부분에서부터 파괴가 시작하기 때 문으로 판단된다.

\section{3 에트링가이트 생성량과 압축강도}

Fig. 10은 에트링가이트 생성량과 재령 3일 압축강도 와의 상관성을 분석한 것으로 에트링가이트 생성량이 증

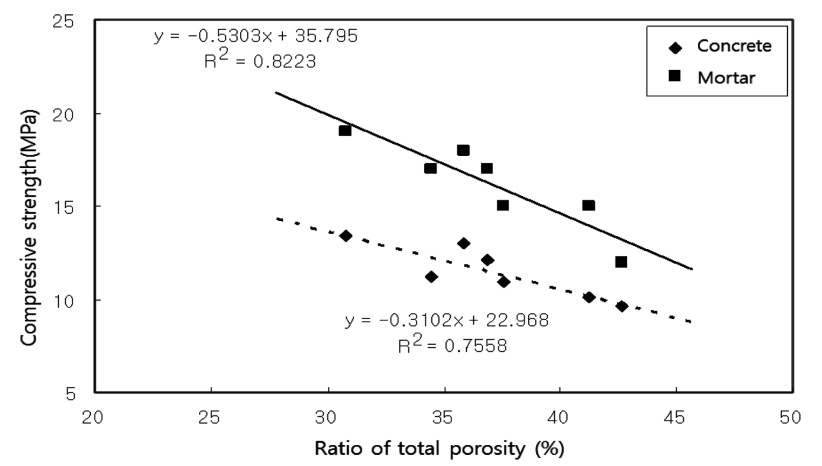

Fig. 9. Correlation between the compressive strength and total porosity.

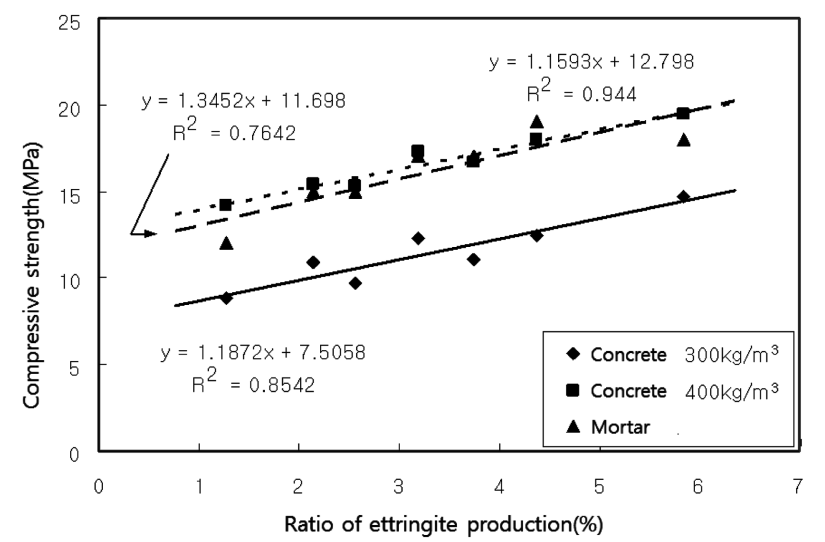

Fig. 10. Correlation between the compressive strength and ettringite production. 
가할수록 모르타르 및 콘크리트의 압축강도가 일정하게 증가하는 경향을 나타내고 있다. 따라서 재령 3 일에서 에 트링가이트 생성량은 압축강도와 일정한 상관성을 유지할 수 있을 것으로 판단된다. 다만, 에트링가이트 수화물은 재령이 경과함에 따라 다른 수화물로 전이되기 때문에 재 령 3일 이후의 에트링가이트 생성량과 압축강도를 직접 적으로 비교하기는 곤란하다.

\section{5. 결 론}

1) 플라이애시 및 CSA 대체에 따른 공기량의 변동은 없으며 슬럼프는 구형의입자로 인하여 약간 높아지는 것 으로 나타났다. 또한 플라이애시만을 사용할 경우 초결 및 종결 시간이 시멘트만을 사용한 배합보다 지연되지만 $\mathrm{CSA}$ 를 첨가할수록 응결시간은 단축되는 현상이 나타났다.

2) 콘크리트 압축강도 측정결과 단위시멘트량 $300 \mathrm{~kg} /$ $\mathrm{m}^{3}$ 에서 플라이애시를 $30 \%$ 대체하고 $\mathrm{CSA}$ 를 $8 \%$ 대체 할 경우 재령 3 일 압축강도는 $12.3 \mathrm{MPa}$ 로 플라이애시만 을 사용한 배합에 비하여 약 $30 \%$ 의 강도 증진 효과가 있는 것으로 나타났으며, 플라이애시 $10 \%$ 만을 사용한 배 합의 $92 \%$ 까지 강도가 접근하는 것으로 나타났다. 단위 시멘트량 $400 \mathrm{~kg} / \mathrm{m}^{3}$ 배합은 $16 \%$ 의 동일 대체량에서 약 $16 \%$ 의 강도 증진 효과가 있었으며, 플라이애시 $10 \%$ 배 합과 비교하였을 경우 $95 \%$ 수준까지 압축강도가 접근 하는 것으로 나타났다.

3) 압축강도에 영향을 주는 유효공극량과 압축강도의 상관성을 분석한 결과 공극량이 증가할수록 압축강도는
낮아지는 것으로 나타났다. 이는 $\mathrm{CSA}$ 를 첨가함으로써 초 기에 에트링가이트의 생성량이 증가하고 강도에 영향을 주는 모세관공극을 채움으로 인하여 강도가 개선된 것 으로 판단된다.

\section{Acknowledgement}

This research was supported by KICT and funded by the Ministry of Science, ICT, and Future Planning. Project No. 2013-0142. 2013 Basic Research: Development of the high durable RC for the artificial land.

\section{References}

1. Y. K. Cho, J. H. Kim, T. Y. Hyun, Concrete \& Slag, Green Solution, p. 125-154, D. B. Si, Korea Iron and Steel Association, Seoul (2012).

2. W. K. Bang, Ph. D. Thesis (in Korea), p. 72-90, Yonsei University, Seoul (1998).

3. K. R. Hwang, Ph. D. Thesis (in Japan), p. 123-157, Tokyo University, Tokyo (1999).

4. Canada Centre for Mineral and Energy Technology, Canadian Electrical Association. Research and Development, High-volume flyash concrete using Canadian fly Ashes, p.78, V. Sivasundaram, Canadian Electrical Association. Research and Development, Ottawa (1994).

5. J. W. Moon, S. W. Ji and C. H. Seo, Kor. J. Arch., 17(5), 8 (2001). 